\title{
The Effect of Flipped Learning Strategy on Developing Saudi University Students' English Reading Comprehension and Their Attitudes towards the Strategy
}

\author{
Noof S. Alharbi \\ English Language Centre (ELC), Taibah University, Saudi Arabia
}

Received August 11, 2021; Revised November 8, 2021; Accepted November 22, 2021

\begin{abstract}
Cite This Paper in the following Citation Styles
(a): [1] Noof S. Alharbi , "The Effect of Flipped Learning Strategy on Developing Saudi University Students' English Reading Comprehension and Their Attitudes towards the Strategy," Linguistics and Literature Studies, Vol. 9, No. 4, pp. 91 - 101, 2021. DOI: 10.13189/lls.2021.090401.
\end{abstract}

(b): Noof S. Alharbi (2021). The Effect of Flipped Learning Strategy on Developing Saudi University Students' English Reading Comprehension and Their Attitudes towards the Strategy. Linguistics and Literature Studies, 9(4), 91 - 101. DOI: $10.13189 / l l s .2021 .090401$.

Copyright $@ 2021$ by authors, all rights reserved. Authors agree that this article remains permanently open access under the terms of the Creative Commons Attribution License 4.0 International License

\begin{abstract}
Flipped Learning Strategy (FLS) has become one of the innovative trends in education to create an exciting learning environment where the instructor becomes a facilitator or guide and students construct their knowledge. Therefore, the current study aimed at investigating the effect of the Flipped Learning Strategy (FLS) on developing university students' English reading comprehension. The study also sought to reveal students' attitudes towards the use of the flipped learning strategy. The study sample consisted of 54 female undergraduate Saudi students enrolled in 102 English courses in the preparatory year at a pioneering university in Saudi Arabia. The students were assigned to two groups: experimental and control. A pre-post reading comprehension test and an attitude scale were used to measure students' attitudes towards FLS. The study revealed that FLS had a positive effect on developing university students' L2 English reading comprehension. The findings also showed a statistical difference at $(\alpha=0.05)$ between the control and experimental groups in the post-reading comprehension test in favour of the experimental group. In addition, the findings pinpointed that students in the experimental group showed positive attitudes towards the use of FLS. The study recommends that much effort should be made by researchers and teachers to implement the FLS in various learning stages to improve the English language in Saudi
\end{abstract}

Arabia. Also, the study provides insight into opportunities for further studies.

Keywords Flipped Learning Strategy (FLS), L2 English, Reading Comprehension, Reading Difficulties, Saudi Arabia, University Students

\section{Introduction}

The new century is witnessing numerous technological and innovative methods. Critical thinking, communication, creativity, and collaboration are the skills that students in the $21^{\text {st }}$ century need to achieve and maintain to prepare them for the future [31]. Therefore, the transfer from traditional pedagogical approaches to more innovative ones is unavoidable. The flipped learning classroom in EFL teaching is one of these innovative pedagogical methods that attracted significant research attention. The Flipped Classroom (FC) model is an innovative classroom structure "that moves the lecture outside the classroom via technology and moves homework and practice with concepts inside the classroom via learning activities” [35] (p.3). Güvenç [22] added that "this flipped classroom 
approach not only helps students learn course content out of the class but also allocates class time for interactive activities, by inverting the conventional teaching model and engaging learners in hands-on practices via group work" (p.421).

Moreover, modern learning theories of constructionism and social constructivism posit that including learners in learning through social interaction contributes to their learning. The current study emphasizes using the flipped learning strategy (FLS) to solve traditional teacher-centred methods. FLS is constructivism-inspired and focuses on how students construct their understanding in collaborative class activities.

\section{Literature Review}

\section{Reading comprehension in EFL}

Reading is a complicated skill because it requires the reader to construct the meaning from the text and understand what has been read. Along the same lines, Lotfi and Siahpoosh [29] defined reading comprehension as 'the ability to communicate a text leading to an integrated process that involves decoding vocabulary and sentences, employing prior knowledge relevant to the text and using cognitive and metacognitive strategies to make sense and to get the target message the author wants to convey' (p.16). They added that 'not being able to either read or comprehend will result in a deep sense of detachment and uselessness' [16] (p.187).

Several studies have confirmed that Arab and Saudi students encounter difficulties in EFL reading comprehension. These studies have identified several causes of these difficulties Alsamadani [6]; Alkhawaldeh [5]; Qrqez \& Rashid [33]; Qrqez \& Ab Rashid [34]. A cause of this difficulty is the ineffective learning strategies or approaches [37-20], which could lead learners not to interact with the text. This, in turn, they will have poor reading skills. Therefore, to achieve comprehension in reading, there is a need to implement new strategies.

\section{Flipped Learning Strategy}

One of the newest trends that are assumed to impact reading comprehension in language learning is the flipped instructional strategy. This strategy has several names, such as blended learning, inverted classroom, and the flip [12]. However, in this study, it will be known as the Flipped Learning Strategy (FLS). According to Milman [30], the concept of the flipped classroom is that "rather than taking up valuable class time for an instructor to introduce a concept (often via lecture), the instructor can create a video lecture, screencast, or vodcast that teaches students the concept, freeing up valuable class time for more engaging (and often collaborative) activities typically facilitated by the instructor" (p.85). Tucker [39] added that the FLS enhances and supplements the learning opportunities for learners. $\mathrm{Pu}$ [32] revealed that the flipped learning strategy enhances students' autonomy, learning attitudes, and motivation in the learning process, promotes peer interaction and develops the students' communication skills.

\section{Theoretical Framework for the Flipped Learning Strategy}

The FLS design is based on the theory of Bloom`s revised taxonomy of the cognitive domain, where students start from the bottom and aim to reach the highest level. They are doing the lower level of work (remembering and understanding) outside class and focusing on the higher forms of cognitive work (application, analysis, evaluation, and creating) in class, where they have the support of their instructor and peers [8]. In accordance with Bloom`s taxonomy, Sams and Bergmann [35] added that students have the chance to maximize and apply interactions between instructor and student and peer and student. The role of the instructor is to guide and assist students throughout the higher forms of the cognitive skills of applying, analyzing, evaluating, and creating in the classroom [23]. Thus, it is believed that the FLS can contribute to students' learning. Figure 1 demonstrates the level of students' learning in the flipped model according to Bloom's taxonomy. 


\section{Traditional Model \\ Flipped Model}

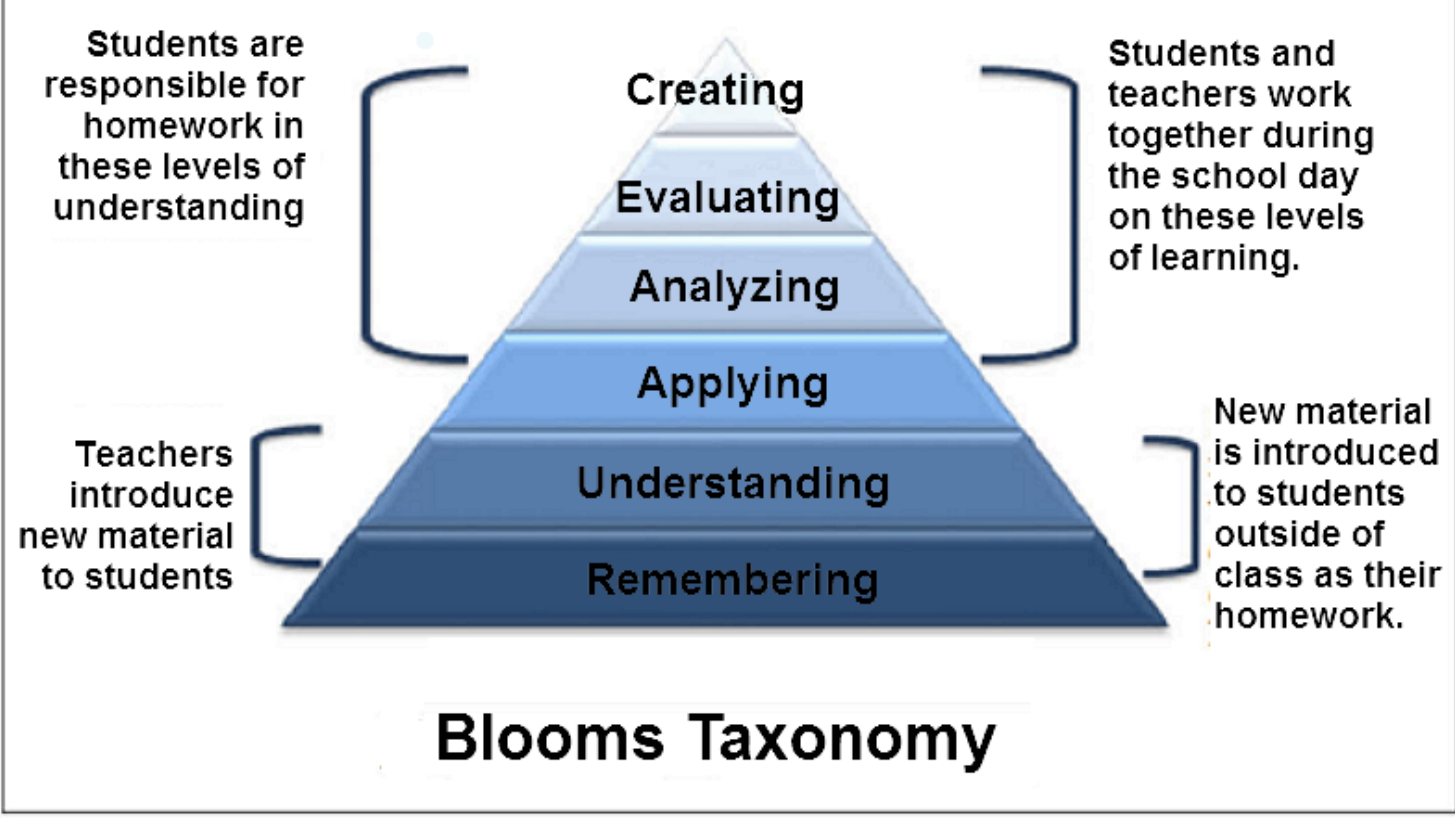

Figure 1. Bloom's taxonomy in the flipped classroom (Jarrah \& Diab, 2019)

\section{The Effectiveness of the Flipped Learning Strategy in EFL Teaching}

It is interesting to note that many studies in recent years have focused on the FLS. Indeed, several studies have been conducted on the application and effectiveness of the FLS in the EFL classroom. For instance, Al-Harbi and Alshumaimeri [3] conducted a study to explore the effect of the flipped classroom strategy on EFL Saudi students' attitudes to and performances in teaching English grammar. The participants were divided into two groups, namely, the experimental group and the control group. The experimental group received instructional videos based on their English textbook, whereas the control group received traditional teaching. The findings showed that students' scores in the experimental group were higher than those in the control group. Moreover, the study revealed that students who were taught using the flipped classroom strategy had more opportunities to communicate in English, which helped support and improve their understanding of the lesson.

Furthermore, Al-Ghamdi [2] carried out a study that explored the application of the flipped classroom strategy on EFL Saudi students' speaking skills. The results revealed that students showed a positive attitude toward applying the flipped classroom experiment and the instructional videos used. Additionally, Güvenç [22] conducted a study to investigate students' views about the flipped classroom approach for teaching writing. The researcher used quantitative survey and qualitative analysis methods to provide rich data from different perspectives. The results demonstrated that most of the students showed positive feelings about the flipped classroom approach.

Another study conducted by Alsowat [7] investigated the effect of a suggested EFL flipped classroom teaching model (EFL-FCTM) on graduate students' English higher-order thinking skills (HOTS), engagement, and satisfaction. Also, the study examined the relationship between satisfaction, HOTS, and engagement. The study sample was (67) graduate female students, who were divided into two groups: a control group and an experimental group. The researcher used a mixed-methods design, including a pre-post HOTS test and two 5-point Likert scale questionnaires to assess satisfaction and engagement. Results indicated statistically significant differences between the English HOTS of the two groups, where the experimental group students obtained higher scores than the control one. Additionally, the results showed a significant difference between the pre-and post-administration of the satisfaction and engagement scale.

\section{Reading Comprehension and the Flipped Learning Strategy}

Concerning reading comprehension, other studies indicated the impact of flipped learning on EFL reading 
comprehension. For instance, Abaeian and Samadi [1] carried out a study to investigate the impact of the flipped classroom strategy on Iranian EFL reading comprehension. The study sample involved 100 female EFL students studying at the Hakim and ZabaneFarda Institutes in Shiraz. They were divided into two groups: control and experimental. The results revealed that the flipped teaching technique had a positive effect on improving students' ability in reading comprehension. In the same vein, Herlindayana's [24] study aimed to explore the impact of a flipped classroom on students' reading comprehension and to examine their perception of the flipped classroom in Indonesia. The study used a mixed-methods design combining quantitative (questionnaire) and qualitative (reading test) designs. From a sample of 30 students, the majority confirmed that the flipped classroom was better than the traditional classroom and developed their reading comprehension.

Furthermore, Karimi and Hamzavi [27] carried out a study to explore the impact of the flipped model of instruction on EFL learners' reading comprehension ability and to identify their attitudes toward the flipped model of instruction in Isfahan. Sixty EFL students were selected for the study and divided equally into an experimental and a control group. The findings revealed that the flipped model of instruction had a significant and positive effect on the reading comprehension ability of the EFL students. Also, the findings showed that the EFL students had a positive attitude towards the flipped model of instruction and that it was helpful for them in different ways.

Another study conducted by Fahmi et al. [21] investigated the teacher's technique of implementing the flipped classroom in teaching reading narrative text and demonstrated students' views of this teaching model. The findings showed that the teacher implemented four main stages in teaching reading narrative text using the flipped classroom model. Furthermore, the students demonstrated positive views of the techniques used in the flipped classroom model. This study suggested implementing this model to target other skills.

Concerning students' attitude towards implementing the FLS, several studies revealed that students have a positive attitude. Sung [38] Sun [37]; Yang, [40]; Zainuddin [42]. For instance, Basal's [9] study implemented a flipped classroom in English language classes in the course "Advanced Reading and Writing I" at Yildiz Technical University. The researcher found that the majority of the students had a positive attitude towards the flipped learning model. In the same vein, Butt [14] aimed to investigate the flipped classroom for undergraduate students in their final-year actuarial course at a university in Australia. A total of 62 students were asked to complete a two-part questionnaire; the first part was about the perceptions of the traditional lecture and the second part was about the flipped classroom. By comparing students' attitudes at the beginning of the semester with their attitudes at the end, the results showed that they preferred tutorials and individual study over lectures and group study. This indicated that they had positive attitudes towards the flipped classroom approach.

Furthermore, Hung [25] carried out a study to examine the possible effect of flipping the classroom on English language learners' academic performance, levels of participation, and learning attitudes. The researcher used three formats of a flipped lesson: non-flipped, structured, and semi-structured flipped lessons. The findings revealed that semi-structured and structured flip lessons were more effective in helping students achieve positive results than non-structured flipped lessons.

Additionally, Ibnian's [26] study investigated the effect of using the FLS on developing university students' reading comprehension in EFL. The study also sought to reveal students' attitudes towards the use of the FLS. The study sample comprised 72 students enrolled in the 101 English Communication Skills course at the World Islamic Sciences and Education University in Amman. The students were assigned to two groups: experimental and control. The study used a mixed-methods design; a pre-post reading comprehension test and a 5-point Likert scale questionnaire had been designed to measure students' attitudes towards the FLS. The study revealed that there are statistically significant differences between the two groups at $(\alpha=0.05)$ in favour of the experimental group. Furthermore, the findings showed that the experimental group had positive attitudes towards the use of the FLS.

Previous studies have confirmed that the FLS can significantly contribute to the EFL classroom in general and EFL reading comprehension. Additionally, students showed a positive attitude toward the application of this strategy.

\section{Statement of the Problem}

As a university instructor in the English language, the researcher observed that most university students face challenges in EFL reading. This observation was also confirmed by the findings of several previous studies conducted on EFL, Arab and Saudi students. These studies revealed that students faced difficulties in EFL reading comprehension Alsamadani, [6]; Alkhawaldeh, [5]; Davoudi \&Yousefi, [20]; Qrqez \& Rashid [33]; Al-Jarrah \& Ismail [4]; Qrqez \& Ab Rashid [34], Ibnian, [28]. Furthermore, the researcher felt the need to respond to the requests from the specialist in teaching the English language to apply various strategies and techniques concerning the improvement of EFL reading comprehension. So, the researcher believed that the FLS could positively affect university students' EFL reading comprehension. To the researcher's best knowledge, to date, no study has investigated the effect of the FLS, 
particularly on reading comprehension for female Saudi students in the preparatory year. The current study fills this gap by exploring the effect of the FLS on developing students' English reading comprehension and their attitude towards this strategy. The two main questions of this study were as follows:

1- What is the effect of using the flipped learning strategy on improving students 'L2 English reading comprehension?

2- What are Saudi university students' attitudes towards the use of the flipped learning strategy?

\section{Methodology}

\section{Design of the study}

A two-group quasi-experimental design was used; this design is preferred where the sample size is small, and randomization and the availability of a control group is impossible. In this study, the random selection of students was not practical [18].

\section{Sampling}

The sampling strategy employed in the current study was convenience or non-probability sampling strategy, where the sample is selected because of their availability and accessibility at the time for the researcher [19]. The students in the sample were at beginner to low intermediate level of proficiency in the English language according to the placement test of the university, which was held at the beginning of the academic year by the English Language Centre (ELC). This level of proficiency in the English language was equivalent to A2 based on the Common European Framework of Reference for Languages (CEFR). These participants were asked to complete the questionnaire and the achievement test; it was decided to administer the questionnaire and achievement test to students online after switching to virtual classes due to the COVID 19 pandemic. To avoid cheating online for the achievement test, the researcher set a time limit to complete the test, preventing students from seeing the previous question after answering them and not displaying the correct answers after finishing the test. In total, 54 female undergraduate students participated in the test, and 27 completed the questionnaire. The sample was restricted to females only due to the privacy of the Saudi society, which prevents the mix of genders in the public and university stage. All the participants were in the preparatory year program (PYP) studying English via virtual classes, as shown in Table 1.

The preparatory year program was developed in $2007 / 2008$ by the ministry of education. Students must be enrolled in this program once they have finished secondary school and before they enter university. Students are expected to complete the requirements in one academic year.

\section{Ethical Considerations}

Before taking part in the study, the participants were given a consent form to sign before conducting the research; therefore, it was guaranteed that the participation of all participants was voluntary. The consent form included all the research information, such as the purpose of the study, the research instruments, and the data analysis [11]. The researcher assured the participants that confidentiality would be maintained and reminded them that they had the right to withdraw from the research at any time or to withdraw any information or any data they had already contributed to. That withdrawal from the study would have no negative effects on them [11]. Pseudonyms were used to maintain participants' anonymity.

\section{Procedures}

The same instructor in one classroom taught the reading skill class. The students attended 4 hours of English classes for four days weekly. The procedures for conducting the current study were divided into five main stages. In the first stage, a pre-reading comprehension test was administered to the participants, divided into an experimental and a control group. In the second stage, the instructor sent an assignment and online activities to the experimental group before the class. In the third stage, the instructor set up a traditional lecture for the control group during the class, whereas the experimental group had a group discussion and activities. In the fourth stage, after the class, the control group had group work and assignments. In the fifth stage, a post-reading comprehension test was administered to the experimental and control groups. In addition, the experimental group was asked to complete a questionnaire to identify their attitudes towards the FLS.

Table 1. Demographic Information about Students Participating in the Questionnaire and Achievement test

\begin{tabular}{|c|c|c|c|c|}
\hline Gender & Year of study & $\begin{array}{c}\text { Number of } \\
\text { students }\end{array}$ & Data Collection & Proficiency level \\
\hline Female & preparatory year & 54 & $\begin{array}{c}\text { Achievement test } \\
\text { Questionnaire }\end{array}$ & A2 \\
\hline
\end{tabular}




\section{Data Collection}

The data were collected from one class with the same level of language proficiency. The achievement test and the questionnaires were sent to the students online through SurveyMonkey after giving their consent to participate in the study. A questionnaire was used to measure female students' attitudes towards the FLS. It consisted of 15 items using a 5-point Likert scale (5) Strongly Agree- (4) Agree - (3) Neutral - (2) Disagree - (1) Strongly Disagree) which is presented in tables separately. In the current study, the structure of the questionnaire was adapted from other relevant studies (Karimi and Hamzayi, [27]; Ibnian, [26]. However, the questionnaire items were developed, reworded, and modified. The achievement test was constructed to assess students' skills in English reading comprehension. It consisted of two reading passages, and each passage included ten items.

\section{Data Analysis}

SPSS descriptive statistical tests were used to analyze the achievement test results and the closed-ended questionnaire items. In the current study, the mean scores, the standard deviations, and the T-test of all the participants' responses were calculated using descriptive statistics.

\section{Validity and Reliability of the Research Instruments}

\section{I- Achievement Test}

The achievement test was constructed to assess the English reading comprehension skills. The final version of the test consisted of 20 items.

\section{Test Validity}

\section{Face Validity}

The test was developed in its initial form to measure the reading skills in English. The test was submitted to ten jury members to assess its face validity in terms of appropriate wording of the test items following the rules governing the formulation of the objective tests and to evaluate the clarity of the test items' language and test instructions. The feedback from the jury members and specialists was taken into consideration (i.e., deletion, modification, or addition of items).

\section{Content Validity}

The test was administered to a pilot sample of 26 female students where Pearson's correlation was calculated between the question mark and the test total mark, as shown in Table 2.

Table 2 showed that the correlations between the test questions and the total test marks are statistically significant at either $(0.01)$ or $(0.05)$, which shows that the test has content validity.

\section{Test Reliability}

Test reliability was calculated using Kuder-Richardson -20 for the objective questions through administering the test on a pilot sample of 26 female students outside the primary sample of the study. The reliability coefficient was (0.89), which indicates high reliability of the test.

Table 2. Pearson's correlation between the question mark and the test total mark

\begin{tabular}{|c|c|c|c|c|c|}
\hline Question & $\begin{array}{c}\text { Correlation of the question with } \\
\text { the total score }\end{array}$ & Sig. & Question & $\begin{array}{c}\text { Correlation of the question with the } \\
\text { total score }\end{array}$ & Sig. \\
\hline Q1 & $.644^{* *}$ & .000 & Q11 & $.558^{* *}$ & .003 \\
\hline Q2 & $.480^{*}$ & .013 & Q12 & $.558^{* *}$ & .003 \\
\hline Q3 & $.748^{* *}$ & .000 & Q13 & $.671^{* *}$ & .000 \\
\hline Q4 & $.748^{* *}$ & .000 & Q14 & $.480^{*}$ & .013 \\
\hline Q5 & $.671^{* *}$ & .000 & Q15 & $.748^{* *}$ & .000 \\
\hline Q6 & $.558^{* *}$ & .003 & Q16 & $.447^{*}$ & .022 \\
\hline Q7 & $.748^{* *}$ & .000 & Q17 & $.603^{* *}$ & .001 \\
\hline Q8 & $.413^{*}$ & .036 & Q18 & $.671^{* *}$ & .000 \\
\hline Q9 & $.488^{*}$ & .011 & Q19 & $.488^{*}$ & .011 \\
\hline Q10 & $.496^{* *}$ & .010 & Q20 & $.671^{* *}$ & .000 \\
\hline
\end{tabular}

* Correlation is significant at the 0.05 level (2-tailed)

** Correlation is significant at the 0.01 level (2-tailed). 


\section{II- Attitude Scale}

\section{Scale Validity}

A questionnaire was used to measure female students' attitudes towards the FLS. The questionnaire consisted of 15 items using a Likert scale (1) Strongly Agree- (2) Agree - (3) Neutral - (4) Disagree - (5) Strongly Disagree. This questionnaire was administered to five jury members and specialists whose feedback was considered (addition, deletion, and modification of items). Content validity was ensured by using the questionnaire on a pilot sample of 26 female students. Pearson's correlation was calculated between the questionnaire items, and the total score was shown in Table 3 below.

Table 3 shows that the attitude questionnaire towards flipped learning is valid.

\section{Scale Reliability}

The attitude questionnaire was administered to a pilot sample where Cronbach's alpha was calculated as (0.90), which shows that the questionnaire is reliable for the study.

\section{Limitation of the study}

One limitation of the present study is that the data collection lasted for only two months due to following the basic schedule of the curriculum specification.

\section{Results}

\section{Pre-Test}

The control and experimental groups were equivalent on the pre-test, as shown in the mean scores. The standard deviations of both groups are shown in Table 4 below.

The results in Table 4 indicate no statistically significant differences exist between the members of the control and experimental groups on the overall pre-testing, indicating the equivalence of the groups.

Table 3. Pearson's correlation for the flipped learning attitude questionnaire items and the total questionnaire score

\begin{tabular}{|c|c|c|c|}
\hline No & Item & $\begin{array}{c}\text { Correlation of the item with the } \\
\text { total score (N=26) }\end{array}$ & Sig. \\
\hline 1 & FLS allowed me to prepare for my English reading class. & $.528^{* *}$ & .003 \\
\hline 2 & FLS made it easier for me to comprehend English reading passages. & $.740^{* *}$ & .000 \\
\hline 3 & I think that my performance on English reading tests is better after applying FLS. & .004 \\
\hline 4 & FLS makes me more responsible for my learning. & $.473^{* *}$ & .007 \\
\hline 5 & The online videos/materials are effective. & $.830^{* *}$ & .000 \\
\hline 6 & I feel more engaged in this reading class after applying FLS. & $.758^{* *}$ & .000 \\
\hline 7 & FLS allowed me to share and discuss the English reading texts with my peers. & $.485^{* *}$ & .006 \\
\hline 8 & I can participate in class using FLS just as I participate in regular classes & $.591^{* *}$ & .001 \\
\hline 9 & FLS motivated me to read English texts independently outside the classroom. & $.695^{* *}$ & .000 \\
\hline 10 & FLS helped me overcome my fear of reading English texts. & $.785^{* *}$ & .000 \\
\hline 11 & The use of FLS helped me overcome English reading challenges. & $.768^{* *}$ & .000 \\
\hline 12 & I am satisfied with selecting what and how to read in English. & $.785^{* *}$ & .000 \\
\hline 13 & FLS makes learning central rather than teaching. & $.676^{* *}$ & .000 \\
\hline 14 & Accessing varied learning materials (video-recorded lectures and reading & $.626^{* *}$ & .000 \\
\hline 15 & material) enhanced different learning styles. & $.700^{* *}$ & .000 \\
\hline
\end{tabular}

**. Correlation is significant at the 0.01 level (2-tailed).

Table 4. The mean scores and the standard deviations for the control and experimental groups

\begin{tabular}{|c|c|c|c|c|c|c|c|}
\hline & Groups & $\mathbf{N}$ & Mean Scores & Std. Deviation & t & df & $\begin{array}{c}\text { Sig. } \\
\text { (2-tailed) }\end{array}$ \\
\hline \multirow{2}{*}{ Scores } & Experimental & 27 & 16.59 & 3.983 & .591 & \multirow{2}{*}{52} & \multirow{2}{*}{.557} \\
\cline { 2 - 7 } & Control & 27 & 15.85 & 5.157 & & \\
\hline
\end{tabular}




\section{Research Question (1)}

What is the effect of using the flipped learning strategy on improving students' L2 English reading comprehension? The Kolmogorov-Smirnov test was used for normality on the pre and post-test administrations for the control and experimental groups, as shown in Table 5 below.

Table 5 shows that female students' scores in the pre-and post-tests are normally distributed. This shows that the T-test could indicate the differences in the mean scores between the members of the control and experimental groups in the pre-and post-tests.

An independent sample T-test was used to ensure that the two groups were equivalent in the pre-administration of the test. The T-Test was used to show the significance of the differences in the mean scores between the control and the experimental groups, as shown in Table 6 below.

Table 7 shows that there is a statistically significant difference at the level $(0.05)$ between the mean scores of the female students of the control and experimental groups in favour of the experimental group with a significance level of (0.003). This result denotes the effectiveness of the FLS in developing female students' English reading skills with a large effect size (eta squared $=0.156$ ).

\section{Research Question (2)}

What are students' attitudes towards using the flipped learning strategy?

The attitude questionnaire was administered to female students in the experimental group. Table 8 shows students' mean scores and standard deviations, demonstrating students' attitudes towards the FLS.

Table 8 shows that students' attitudes towards the FLS were high, as shown in their mean scores (3.69) and standard deviation (0.389). Based on Table 8, the overall mean score of students' attitudes towards the FLS was (3.69) with a standard deviation of (0.389).

The results from the questionnaires show that the students had a positive attitude towards implementing the FLS. The students revealed that they felt more engaged in this reading class after applying the FLS $(\mathrm{M}=4.19$, SD.1.039). They also indicated that the FLS helped them overcome their fear of reading English texts $(\mathrm{M}=3.96$, SD.437) and prepare for their English reading class (M. 3.81, SD.1.001).

Table 5. Tests of normality for students' scores in the reading test

\begin{tabular}{|c|c|c|c|c|c|c|c|}
\hline \multirow{2}{*}{ Test } & \multirow{2}{*}{ Group } & \multicolumn{3}{|c|}{ Kolmogorov-Smirnov ${ }^{a}$} & \multicolumn{3}{|c|}{ Shapiro-Wilk } \\
\hline & & Statistic & df & Sig. & Statistic & df & Sig. \\
\hline \multirow{2}{*}{ Pre-test } & Experimental & .113 & 27 & $.200^{*}$ & .964 & 27 & .458 \\
\hline & Control & .100 & 27 & $.200^{*}$ & .962 & 27 & .418 \\
\hline \multirow{2}{*}{ Post-test } & Experimental & .145 & 27 & .151 & .927 & 27 & .057 \\
\hline & Control & .123 & 27 & $.200^{*}$ & .936 & 27 & .097 \\
\hline \multicolumn{8}{|c|}{ *. This is a lower bound of the true significance. } \\
\hline \multicolumn{8}{|c|}{ a. Lilliefors Significance Correction } \\
\hline
\end{tabular}

Table 6. Independent samples T-test for the control and experimental groups

\begin{tabular}{|c|c|c|c|c|c|c|c|}
\hline \multirow{3}{*}{ Pre-Test } & Group & N & Mean Scores & Std. Deviation & t & df & Sig. (2-tailed) \\
\cline { 2 - 7 } & Experimental & 27 & 12.33 & 2.465 & .218 \\
\cline { 2 - 6 } & Control & 27 & 12.19 & 2.527 & & \multirow{2}{*}{.828} \\
\hline
\end{tabular}

Table 7. The mean scores, standard deviations, and T-test were calculated to measure the difference in mean scores between the control and the experimental groups in the post-test.

\begin{tabular}{|c|c|c|c|c|c|c|c|c|c|}
\hline \multirow{3}{*}{ Post-Test } & Group & N & $\begin{array}{c}\text { Mean } \\
\text { Scores }\end{array}$ & Std. Deviation & t & df & Sig. (2-tailed) & Eta Squared & Effect Size \\
\cline { 2 - 9 } & Experimental & 27 & 16.96 & 2.457 & \multirow{2}{*}{3.105} & 52 & .003 & .156 \\
\cline { 2 - 8 } & Control & 27 & 14.41 & 3.500 & Large \\
\hline
\end{tabular}


Table 8. The mean scores and standard deviations of students' attitudes towards the FLS

\begin{tabular}{|l|l|c|c|c|}
\hline No & Items & $\begin{array}{c}\text { Mean } \\
\text { Scores }\end{array}$ & $\begin{array}{c}\text { Std. } \\
\text { Deviation }\end{array}$ & Level \\
\hline 1 & FLS allowed me to prepare for my English reading class. & 3.81 & 1.001 & large \\
\hline 2 & FLS made it easier for me to comprehend English reading passages. & 3.56 & .847 & large \\
\hline 3 & I think that my performance on English reading tests is better after applying FLS. & 3.44 & .892 & large \\
\hline 4 & FLS makes me more responsible about my learning & 3.56 & .847 & large \\
\hline 5 & The online videos/materials are effective. & 3.67 & .961 & large \\
\hline 6 & I feel more engaged in this reading class after applying FLS. & 4.19 & 1.039 & large \\
\hline 7 & FLS allowed me to share and discuss the English reading texts with my peers. & 3.67 & .679 & large \\
\hline 8 & I can participate in class using FLS just as I participate in regular classes & 3.78 & .506 & large \\
\hline 9 & FLS motivated me to read English texts independently outside the classroom. & 3.48 & .849 & large \\
\hline 10 & FLS helped me overcome my fear of reading English texts. & 3.96 & .437 & large \\
\hline 11 & The use of FLS helped me overcome my English reading challenges. & 3.70 & .823 & large \\
\hline 12 & I am satisfied with selecting what and how to read in English. & 3.63 & .742 & large \\
\hline 13 & FLS makes learning central rather than teaching. & 3.56 & .934 & large \\
\hline 14 & $\begin{array}{l}\text { Accessing varied learning materials (video-recorded lectures and reading material) } \\
\text { enhanced different learning styles. }\end{array}$ & 3.59 & 1.118 & large \\
\hline 15 & Classroom time in FLS is used effectively & 3.81 & .622 & large \\
\hline & Total & 3.69 & .389 & large \\
\hline
\end{tabular}

\section{Discussion}

This study aimed to explore the effect of the FLS on developing students' reading comprehension and identifying female students' attitudes toward this strategy. The first research question examined whether the FLS has any statistically significant effect on students' English reading comprehension. The study results showed that the FLS had a significant positive effect on developing university students' English reading comprehension skills. These results are consistent with the findings of other studies conducted by Abaeian \& Samadi, [1]; Herlindayana et al. [24]; Karimi \& Hamzavi, [27].

The second research question aimed to identify female students' attitudes toward the FLS. The results of the frequency analysis demonstrated that mostly students had a positive attitude towards this strategy. These outcomes are supported by the results of Basal [10], Butt [14], and Hung [25], who revealed that students have a positive attitude toward the use of the FLS to improve their EFL reading comprehension skills and develop a positive attitude towards EFL reading comprehension.

Students pointed out that they felt more engaged in this reading class after applying the FLS. This result corroborates with the findings of Alsowat [7], who pointed out that the FLS is better at engaging students than are traditional forms of instruction. It also presents them with more frequent opportunities to communicate in English. In addition, the FLS encourages students to learn English by implementing a range of innovative activities.

One of the findings in the current study pointed out that the FLS enhanced different learning styles by using varied online materials, which contributed to overcoming their English reading challenges. These findings agreed with the results of Ibnian [26], which indicated that using technology in the FLS encouraged students' various learning styles. Furthermore, students indicated that the FLS encouraged them to discuss and communicate with their peers. These findings are supported by Zainuddin and Halili [41], whose findings revealed that using the FLS improves students' collaborative learning environment. Thus, it can be observed from the above that the FLS plays a significant role in developing university students' English reading comprehension skills because applying this strategy will 'enhance EFL learners' English proficiency, promote their autonomy, motivation, learning attitudes and engagement in the learning process, foster peer interaction and improve learners' communicative skills' [32] (p.310). These benefits allowed the students in the current study to have a positive attitude towards implementing this strategy. In short, the current study results may facilitate adapting and developing the teaching methods in EFL classes to improve or modify strategies towards a more student-centred approach and achieve the best outcomes in the learning process.

\section{Conclusions}

The current study aimed to explore the effect of the FLS on developing university students' reading comprehension in EFL classes. The study also sought to reveal students' attitudes towards the use of the FLS. The findings revealed that the effectiveness of the FLS 
resulted in developing university students' English reading comprehension skills, which answers the first research question. Moreover, the study showed that the students had a positive attitude towards implementing this strategy, which answers the second research question.

\section{Recommendations and Suggestions}

Based on the findings, the researcher recommends that curriculum developers, instructors, and researchers in the field of EFL examine and implement the FLS for developing the English language in different learning stages, primary, intermediate, and secondary, to create a more active learning environment for learners. More attention should be paid to preparing workshops and training courses for EFL instructors on new applications and teaching strategies, including flipped learning strategy. Furthermore, the researcher suggests conducting studies tackling:

- The effect of flipped learning strategy on developing other English language skills of listening, writing, speaking.

- The effect of the flipped learning strategy on self-directed learning in the English language among Saudi students.

- Compare the effect of the flipped learning strategy on achievement and attitudes to the English language on both genders.

\section{REFERENCES}

[1] Abaeian, H., \& Samadi, L. (2016). The effect of flipped classroom on Iranian EFL learners' L2 reading comprehension: Focusing on different proficiency levels. Journal of Applied Linguistics and Language Research, 3(6), 295-304.

[2] Al-Ghamdi, M., \& Al-Bargi, A. (2017). Exploring the application of flipped classrooms on EFL Saudi students' speaking skill. International Journal of Linguistics, 9(4), 28-46.

[3] Al-Harbi, S., \& Alshumaimeri, Y. (2016). The flipped classroom impact in grammar class on EFL Saudi secondary school students' performances and attitudes. English Language Teaching,9(10), 60-80.

[4] Al-Jarrah, H., \& Ismail, N. (2018). Reading comprehension difficulties among EFL learners in higher learning institutions. International Journal of English Linguistics, 8(7), 32-41.

[5] Alkhawaldeh, A. (2012). The EFL reading comprehension challenges faced by secondary school students in Jordan. European Journal of Social Sciences, 35(2), 140-152.

[6] Alsamadani, H. (2009). The relationship between Saudi EFL college-level students' use of reading strategies and their
EFL reading comprehension. An Unpublished PhD Dissertation, Ohio University.

[7] Alsowat, A. (2016). An EFL flipped classroom teaching model: Effects on English language higher-order thinking skills, student engagement and satisfaction. Journal of Education and Practice, 7(9).

[8] Anderson, L., Krathwohl, D., Airasian, P., Cruikshank, K., Mayer, R., Pintrich, P., Raths, J., \& Wittrock, M. (2000). A taxonomy for learning, teaching, and assessing: A revision of Bloom's taxonomy of educational objectives. New York: Pearson, Allyn \& Bacon.

[9] Basal, A., \& Aytan T. (2014). Using Web 2.0 Tools in English Language Teaching. Turkish Online Journal of Distance Education,16(4).

[10] Başal, A., \& Aytan, T. (2014). Using Web 2.0 tools in English language teaching. In Conference proceedings. ICT for language learning (p. 372). Libreriauniversitaria. it Edizioni.

[11] BERA (2004). Revised ethical guidelines for educational research. British Educational Research Association.

[12] Bergmann, J. \& Sams, A. (2012). Flip your classroom: Reach every student in every class every day. International Society for Technology in Education (ISTE). ASCD.

[13] Bergmann, J. \& Sams, A. (2012). Flip your classroom: Reach every student, in every class, every day. Oregon: Courtney Burkholder.

[14] Butt, A. (2014). Student views on the use of a flipped-classroom approach: Evidence from Australia. Business Education \& Accreditation, 6(1), 33-43.

[15] CAD Guide: The flipped classroom. Nottingham Trent University, Centre for Academic Development and Quality. Retrieved from https://www4.ntu.ac.uk/adq/document_uplo ads/teaching/154084.pdf

[16] Celce-Murcia, M. (2001). Teaching English as a second or foreign language. Boston: Heinle \& Heinle, Thomson learning, Inc.

[17] Chi Cheung Ruby Yang. (2017). An investigation of the use of the 'flipped classroom' pedagogy in secondary English language classrooms. Journal of Information Technology Education: Innovations in Practice.16, 1-20.

[18] Cohen, L., Manion, L. \& Morrison, K. (2007). Research methods in education. Routledge.

[19] Cohen, L., Manion, L., \& Morrison, K. (2011).Research methods in education. Routledge.

[20] Davoudi, M., \& Yousefi, D. (2015). Comprehension breakdown: A review of research on EFL learners`reading difficulty and problems. International Journal of Language and Applied Linguistics, 1(1), 58-72.

[21] Fahmi, R., Friatin, L., \& Irianti, L. (2020). The use of flipped classroom model in reading comprehension. Journal of Applied Linguistics and Literacy (JALL), 4(1), 77-94.

[22] Güvenç, G.(2018). The flipped classroom approach in teaching writing: An action research. International Journal of Social Sciences and Education Research. 4(3), 421-432. 
[23] Hamdan, N., McKnight, P., McKnight, K. and Arfstrom, K. M. A review of flipped learning. Available: http://www.flippedlearning.org/cms/lib07/VA01923112/Ce ntricity/Domain/41/LitReview_FlippedLearning.pdf,2013.

[24] Herlindayana, H., Sahlan, S., \& Alberth, A. (2017). The Effect of Flipped Classroom on Students' Reading Comprehension. Journal of Language Education and Educational Technology (JLEET), 2(1).

[25] Hung, H. (2015). Flipping the classroom for English language learners to foster active learning. Computer Assisted Language Learning, 28(1), 81-96.

[26] Ibnian, S.(2019). The Effect of Using the Flipped Learning Strategy on Developing University Students' Reading Comprehension in EFL and their Attitudes towards the Strategy. Al-Manarah, 25(1),437-458.

[27] Jarrah, A., \& Diab, K. (2019). The Effect of Flipped Classroom Model on Students' Achievement in the New 2016 Scholastic Assessment Test Mathematics Skills. Online Submission, 5 (3), 769-777.

[28] Karimi, M., \& Hamzavi, R. (2017). The effect of flipped model of instruction on EFL Learners' reading comprehension: Learners' attitudes in focus. Advances in Language and Literary Studies, 8(1), 95-103.

[29] Lotfi Sin, S. \& Siahpoosh, H. (2020). Looking at the impact of the flipped classroom model on reading comprehension of Iranian EFL learners. Arabic Language, Literature \& Culture.5(2), 14-22.

[30] Milman, N. (2012). The flipped classroom strategy: What is it and how can it be used? Distance Learning, 9(3), 85-87.

[31] Owston, R., York, D., \& Murtha, S. (2013). Student perceptions and achievement in a university blended learning strategic initiative. The Internet and Higher Education. 18, 38-46.

[32] Pu, F. (2017). Review of research on EFL flipped teaching. Advances in Social Science, Education and Humanities Research, Vol.142，308-311，2017. $4^{\text {th }}$ International Conference on Education, Language, Art and Inter-cultural
Communication (ICELAIC).

[33] Qrqez, M. \& Rashid, R. (2017). Reading comprehension difficulties among EFL learners: The case of first- and second-year students at Yarmouk University in Jordan. Arab World English Journal, 8(3), 421-431.

[34] Qrqez, M. \& Rashid, R. (2019). The sources of reading comprehension difficulties among Saudi EFL learners. Trends in Social Sciences (TSS), 1(1), 7-16.

[35] Sams, A. and Bergmann, J. (2013). Flip your students' learning. Educational Leadership, 70(6), 16-20.

[36] Strayer, J. (2007). The effects of the classroom flip on the learning environment: A comparison of learning activity in a traditional classroom and a flip classroom that used an intelligent tutoring system (Doctoral dissertation, The Ohio State University).

[37] Sun, Y. C. (2017). Flipping every student? A case study of content-based flipped language classrooms. E-Learning and Digital Media, Vo.4.No.(1-2), 20-37.

[38] Sung, K. (2015). Case study on a flipped classroom in an EFL content course. Multimedia-Assisted Language Learning,18(2), 159-187.

[39] Tucker, B. (2012). The flipped classroom. Education Next,12(1), 82-83.

[40] Yang, C. (2017). An investigation of the use of the 'flipped classroom' pedagogy in secondary English language classrooms. Journal of Information Technology Education: Innovations in Practice, 16(1).

[41] Zainuddin, Z. \& Halili, S. (2016). Flipped classroom research and trends from different fields of study. International Review of Research in Open and Distributed Learning, 17(3).

[42] Zainuddin, Z. (2017). First-year college students' experiences in the EFL flipped classroom: a case study in Indonesia. International Journal of Instruction, 10(1), $133-150$. 